\title{
Conceptualising the labour-money connection: a critical re-examination of Benetti and Cartelier's Marchands, salariat et capitalistes
}

\author{
RICHARD SOBEL \\ CLERSÉ-UMR 8019-CNRS, Université Lille 1
}

\author{
NICOLAS POSTEL \\ CLERSÉ-UMR 8019-CNRS, Université Lille 1
}

\begin{abstract}
Carlo Benetti and Jean Cartelier's Marchands, salariat et capitalistes (1980) may be seen as a French attempt to develop a radical "monetary" paradigm, designed to counter the dominant neoclassical model. In this article, we argue that while the monetary approach is necessary for an epistemological break from orthodoxy, it is insufficient for the development of a genuinely heterodox paradigm. The problem is its conceptual limitation to a form of "monetary purism". This approach is limited by a form of "monetary purism" and this limitation makes it incapable of attributing any theoretical status either to the labour force or to the wage-labour nexus.
\end{abstract}

Keywords: monetary approach, heterodoxy, wage-labour nexus, labour force, Marxism, institutionalist political economy

JEL Classification: B24, B25, B31, B51

Marchands, salariat et capitalistes (1980) may be seen as a French attempt to develop an alternative to the dominant neoclassical paradigm. In contrast to the real approaches to the economy which characterise the mainstream approach, Carlo Benetti and Jean Cartelier start with the monetary institution of the economy, by recognizing its ontological primacy, and then form the basis of political economy by guaranteeing its autonomy within the other social sciences. This piece has had a certain lasting academic impact, though largely limited

AUTHORS' NOTE: The authors are grateful for helpful comments from two anonymous referees and from the editors of EJPE, especially Tyler DesRoches. This article benefited from the assistance of National Agency Research, France (theme: "The CSR: institutional transition or return of paternalism?” Reference: ANR-09-JCJC-132-01). 
to France. ${ }^{1}$ Unless we are willing to conclude that its approach is no longer relevant-except as a touchstone in the history of French economic thought-it may be worth pausing to enquire what use may still be made of such a monetary analysis some thirty years after its initial publication.

In this paper, we propose the following hypothesis: the monetary approach at the core of Benetti and Cartelier's work is a necessary but insufficient component in the construction of a heterodox paradigm in economics. ${ }^{2}$ Such an approach is necessary insofar as it provides a solid and precise social-historical definition of the political (Castoriadis 1998) and thus avoids the economism to which the formal definition leads (Polanyi 1977) The monetary approach makes possible a conceptual distinction between 'the market economy' and 'capitalism' (a distinction which is all the more important given that the neoclassical mainstream makes no such distinction, and even lacks the theoretical means to consider such a differentiation). In so doing, the monetary approach advances a definition of one of the fundamental institutions of capitalism, the wage-labour nexus, that, as we shall demonstrate, is profoundly reductive and ultimately limits the range of the heterodox paradigm that Benetti and Cartelier intended to construct. Their model invites a twofold critique and this shall be our task in the pages that follow. This is not simply a question of clarifying a problem in the history of contemporary heterodox economic thought, but also a matter of showing how this theoretical approach was never integrated with the more applied methods such as those of the Paris School of Regulation or the School of Conventions (Postel and Sobel 2011)-a failure which weakened heterodox economic thought in France during the late 1980s when the neoclassical trend dominated the academic field.

In the first section, we situate Benetti and Cartelier's monetary approach within the context of theoretical debates regarding French heterodoxy from the late 1970s to the mid 1980s. In the second section, we reveal how this approach redefines the salary relationship as a social relationship of monetary dependence, highlighting the problems it poses for economic analysis. Specifically, it is shown that when the

\footnotetext{
${ }^{1}$ Demonstrated, perhaps, by the absence of any English translation of the work to date. On the reception, history, and influence of the book, see Schwab, et al. 1985.

${ }^{2}$ Our contribution is consistent with the recent approach which has given rise to Carlo Benetti and Jean Cartelier's publication of a collective work on the monetary perspective on the economy (Ulgen, et al. 2013), in which these two economists return to Marchands, salariat et capitalistes "thirty years later".
} 
salary relationship is used to define labour from an economic perspective, labour itself disappears from the analysis. In the third section, we show that Benetti and Cartelier's interpretation of the postulate that "the monetary form of social relationships is logically independent of the material description of actions that it covers" gives rise to a paradox (Cartelier 1996b, 89). ${ }^{3}$ This conceptualization reduces labour to an anthropological category, displacing it from political economy, and thus underdetermining the nature of that dependence and reducing it to a mere monetary operation. At the same time it leads to the rejection of an understanding of concrete economic forms from a socio-economic historical approach, which has been academically devalued because it is not sufficiently pure from such a theoretical point of view.

This article contributes to theoretical debates between French heterodox economists that took place thirty years ago. However, this article also endeavours to make a broader contribution. By analysing these debates, especially the place of Marxism in heterodoxy, we are contributing to a current initiative to reformulate the basis of institutionalist political economy, ${ }^{4}$ by trying to determine what lessons from this past experiment could help in constructing a heterodox approach today.

\section{MARCHANDS, SALARIAT ET CAPITALISTES: A RADICAL INSTITUTIONALIST PERSPECTIVE}

\section{The institutionalist basis of the French critique of political economy}

During the 1980s, French historians of economic thought engaged in what might be described as a critique of political economy. ${ }^{5}$ This

\footnotetext{
${ }^{3}$ All translations from Marchands, salariat et capitalistes that appear in this essay are our own.

${ }^{4}$ Here we are referring to the Manifeste vers une économie politique institutionnaliste, ${ }^{4} \mathrm{a}$ process launched in 2007 by the representatives of three branches of French heterodox economics: Alain Caillé (anti-utilitarian theory), Robert Boyer (regulation theory), and Olivier Favereau (convention theory). The authors start with the ideal-typical assessment that there are two approaches to economics, economics as a science and political economics, and announce that they will defend the latter by restructuring it and reinforcing it through an alliance with the most recent trends in institutionalism. This text (available in French and English on the site of La Revue du MAUSS, see Caillé 2007) was written by Alain Caillé, with the collaboration of Olivier Favereau and Robert Boyer. (José Luis Corragio, Peter Hall, Geoffrey Hodgson, Marx Humbert, Ahmet Insel, Michael Piore, Ronen Palan, Paul Singer, Bob Jessop, Jean-Louis Laville, Michel Lallement, Philippe Steiner, and François Vatin were also involved.)

${ }^{5}$ We adopt this expression to refer to the scholars behind this approach who had works published by Maspero and contributed major articles to the Cahiers d'Économie
} 
approach examined the possible conditions for a heterodox paradigmone that might supplant the neoclassical model. The goal was to situate themselves at the same level of conceptual generality and to establish a theory of capitalist market economies, not simply market economies (Cartelier 1983; 1985; and 1991; and De Vroey 1987). Marchands, salariat et capitalistes can be viewed as the cornerstone, and perhaps a symbol, of this intellectual period. It represents the ambitions, contributions, and limitations of the underlying theoretical project. ${ }^{6}$

The authors of this school have introduced the foundation of a heterodox paradigm made possible by a return to the basic premises of Marx and Keynes. ${ }^{7}$ On the Marxian side, once all dogmatism arising from dialectical materialism is removed (Faccarello 1981, and 1982; De Vroey 1984b; Gouverneur 1987; Benetti and Cartelier 1998), it is a question of revisiting the analysis of the two social relationships structuring the capitalist economy: the market form of the products of labour and the salaried form of the use of labour. From Keynes's perspective, and complementary to the mobilisation of Marx, it is a matter of emphasizing the basic role of money as a socio-economic institution and the decisive role of the entrepreneur as a key actor in capitalism. These fundamental ideas enable one to grasp the institutional nature of capitalism, while never losing sight of the ahistorical character of theoretical categories such as rationality and 'the market'.

Behind this heterodox perspective is a radical difference in the conception and epistemological status of institutions which stands in marked contrast to the neoclassical approach. ${ }^{8}$ Basic components of

Politique, a journal they helped to create and manage. It is important not to confuse these authors with other heterodox economists who published studies from a regulationist perspective in the journal Critique de l'Économie Politique (Nouvelle Série [New Series]), also published by Maspero, at around the same time.

${ }^{6}$ We do not underestimate the diversity of research in this branch of heterodoxy, but in general terms, for our purposes, this shorthand grouping is appropriate. As we will see, Carlo Benetti and Jean Cartelier have radicalised the monetary approach, which is merely one element dividing heterodoxy and orthodoxy.

${ }^{7}$ Research following this approach has mostly examined very general questions, and, in fact, has not managed to effect a fruitful and sustainable collaboration with more empirical heterodox methodologies, such as Boyer and Saillard's (2002) theory of regulation.

${ }^{8}$ In this article, the term 'institutionalism' and the adjective 'institutionalist' are not used in the customary academic sense to refer to a trend in economic analysis, whether the old American institutionalism (e.g., Commons) or neoinstitutionalism (e.g., North, and Williamson). In the French intellectual arena, they signal a common characteristic of heterodox economics, the taking into account of institutions in an 
the modern construction of the economy as capitalist-institutions such as money, merchandise and the wage system-must not be reduced to merely the results of individual interactions, as if one were dealing only with a transaction between autonomous agents. Clarifying this point jettisons the constructivist illusion of methodological individualism, an idea that drives the debatable fiction according to which society can be produced by individuals out of nothing, a fiction that obscures both the actual nature of these institutions and the social relationships that they initiate and cause to function. Although such terminology is never employed by the authors, it is precisely this 'institutionalist' dimension that we believe to be at the heart of Benetti and Cartelier's analysis. It constitutes a compelling break from what is today considered the best approach to economic theorization: micro-foundations research on the basis of the universal axiom of the instrumental (and ultimately strategic) rationality of homo economicus (Lazear 2000).

Neoclassical theory-particularly in its most recent contractualist version-never confers an autonomous role on institutions. ${ }^{9}$ Institutions are the explanandum and never the explanans. Contrary to this, institutionalist heterodoxy emphasizes the structures of the economy which very strongly condition the actions of economic agents. Marx was certainly the one who insisted the most on this institutional conditioning. Let us first recall the Marxian issue. To grasp the mode of capitalist production, Marx starts by constructing the theoretical fiction of a merchant society (C-M-C'). The economy is comprised of independent merchant producers, who specialize in a type of production (C, C'), whose social division of labour will provide all that the community requires. Each producer sells the product of their labour in the form of merchandise, to have access to money, its general equivalent, allowing access to other necessary merchandise. All merchandise (whether goods or services) appears as a social object with two dimensions: a use value (which represents its useful character for an economic agent with needs to satisfy) and an exchange value (based on the average quantity of abstract work socially necessary for its production at a particular point in time given the functioning of the economy, which we label work-value). The use value is the concrete support for the exchange value, but does not determine it, either in

approach which stems neither from methodological individualism, nor from holism or structuralism, see Postel and Sobel 2009.

${ }^{9}$ For the purpose of this paper, we will not revisit the institutional presuppositions from the perspective of neoclassical thought. 
terms of its substance (the general work) or in terms of its scale (time of work). It is impossible to compare the merchandise from the point of its use value, but equivalent values in terms of exchange value may be determined since they all participate in a common substance, work value (Marx 1995 [1867], henceforth Capital).

In the fiction Merchandise 1-Money-Merchandise 2, use value is more important than exchange value and its representative, money. The latter is merely the means at the service of a social process which puts human need in the forefront. For Marx there is now, at the heart of modern societies, an inversion of this process: economic agents ("capitalists"), through the intermediary of generalized commercial exchange, aim at another end result than the satisfaction of a particular need: Money 1-Commodity-Money 2. This other outcome is the growth in the quantity of money (' $\Delta$ Money' being the surplus value), unlimited growth, sought for its own sake, the general equivalent of 'capital accumulation'.

For Marx, the origin of the growth in value was located in a specific exchange (the salary trade) and in leaving the area of the circulation of merchandise to descend into the realm of the production of merchandise. The economy is not a socially homogenous domain but instead finds itself split into two classes of economic agents. Indeed, from a sociological and historical perspective, there are certainly other social classes; but here the reasoning is structural and only considers the basic cleavage, the capital-labour relationship or the wage-labour nexus, established through violence ('the primitive accumulation of capital', described in Capital, volume 1, chapter 23) and reproduced especially by the government, the political instrument at the service of this class domination.

The capitalists, on the one hand, possess a quantity of capitalmoney, a pure form of capital, which they seek to increase through the exploitation of the workforce which they pay. Thus, they themselves have the potential to initiate a process of production of merchandise for their own enrichment.

The proletariat, on the other hand, possesses only their labour power, and all they can do is seek to rent it out to live. This relationship of subordination is not at all a commercial exchange: the salary is obtained in exchange for availability to perform certain tasks, within a particular context and over a specific period of time, for the usage 
of the labour power, the latter, unlike real merchandise-being indistinguishable from its holder.

For Marx, labour power is a particular form of merchandise. Its use value is none other than the creative power of human labour. To have access to the use of this power, the capitalist has only to pay an employee a flat rate: the exchange value of labour power, which corresponds to the value of the merchandise necessary to maintain and reproduce the labour power. This value is less than that the employee can create over the period during which the capitalist rents the use of the labour power. This difference is the surplus value which follows the use/exploitation of labour power after the undefined/indefinite productivity of the use value and at the simple cost of the exchange value.

Marx's theory has a common point of departure with many other heterodox schools-e.g., Keynesian, institutionalist, regulationist, and conventionalist schools (Lawson 2006). In all such cases, institutions are not treated as the systematic and contemporary creations of agents. Heterodox approaches have a theory of the origin of institutions; but, unlike the orthodox approach, this theory is not, properly speaking, 'economic'. ${ }^{10}$ Instead, it depends on other social sciences-history, political science, anthropology, and so on-and thus calls for a multidisciplinary approach to economic institutions.

This attempt to construct a heterodox paradigm never went very far and did not give rise to a collective research dynamic. Indeed, the fact that the French heterodox model saw its development slow down at the end of the1980s is relevant in terms of academic strategies operating within French economics itself, and can perhaps be best understood from the perspective of the sociology of this field. The political and intellectual context of these years experienced a general loss of credibility for Marxist thought (Pouch 2001), and structuralist thinking in the social sciences more generally. For reasons of space, our contribution here cannot address this critical context in any detail;

\footnotetext{
${ }^{10}$ One must depend on the permanent wordplay which neoclassical theory requires in its usage of the term 'economic'. This term designates either an area of social life-the economic realm as a collection of concurrent acts and institutions anywhere and anytime, but in the social-historical forms specific to the productiondistribution-consumption of resources necessary to individual and collective life, i.e., a "substantive" definition according to Karl Polanyi (1977)—or behaviour-'economic' behaviour being that which seeks the most for the least, i.e., an ahistorical anthropological form of homo economicus according to Polanyi's formal definition. What the mainstream calls 'economic analysis' falls completely outside of the formal definition.
} 
rather our focus is on constructing an alternative paradigm within the framework of the current academic situation. ${ }^{11}$ While we are not certain that Benetti and Cartelier would formulate the issues in this way, and however far it may be from exhausting the full original heterodox contribution of their monograph, we nonetheless find at the centre of their work a theoretical conviction consistent with our own that heterodoxy must find its unity on the basis of an institutionalist perspective of what can be defined as economic.

\section{The prevalence of the monetary institution of the economy}

The essential core of Benetti and Cartelier's theoretical contribution lies in its definition of the monetary institution of the economy and, in association with that, in its radical critique of the current real approach. In a short essay to clarify this point, written prior to the publication of Marchands, salariat et capitalistes, Carlo Benetti and Jean Cartelier (1995) remark that since the birth of economics, economic theorists have been careful to focus only on social relations that are quantifiable:

for the most part, economists have traditionally focused on relations that can be quantified (through money and accounting) and have left the others (family, political relations, religious and symbolic practices, etc.) to other specialised fields. In other words, it is because certain social relations are expressed in monetary terms and in things (goods), that they are associated with a particular area of reflection. Beyond these various interpretations, economists were taken with the same subset of social relations, formed by relations appearing to be the major ones. The central point is that the key relations at play here are not those constructed by theoreticians. They are the result and substance of the individuals' own practices (Benetti and Cartelier 1995, 218).

Benetti and Cartelier clearly favour the substantive definition of what is economic, but they believe that it must be further developed to discern the social-historical nature of the real goal of political economy. Economic reality, the subject of orthodox economic theory, is primarily comprised of specific major factors that appear in all societies in the daily life of human beings. Economic science, in the form of political economy, has received its impetus western society in which-while serving the spread of capitalism-these particular quantitative

\footnotetext{
${ }^{11}$ For more precision about this academic situation, we can refer to the website of the French Association for Political Economy: www.assoeconomiepolitique.org
} 
relationships developed and formed a system in an objectifiable manner. The "immediately" quantitative nature of economic reality could always appear as a strong indicator of its objectivity and therefore as a guarantee of a "natural" economic science. Thus rendering economics distinct from other, equivalent, if sometimes obscure, forms of social knowledge such as sociology, political science or history. Yet the form of conceptuality from which economic theory principally developed was not content with this first level of objectivity, and always looked beyond this monetary "appearance" for the so-called "essence" of the economic subject matter which, up to that point, had only revealed itself phenomenally in economic practices.

Throughout the history of economic thought, this search for the essence of what is economic has characterised the paradigmatically dominant "realistic approach", as opposed to the paradigmatically dominated monetary approach, that, while repeatedly rejected, has just as consistently re-emerged in such models as Keynes's monetary production economy (Schumpeter 2000 [1954]). Consequently, it has led to a divided opposition. On one hand, analysis in real terms is based on the principle that all economic phenomena may be fundamentally described in terms of goods and services or, more precisely, in terms of decisions concerning them and the relations between them, money itself being merely a veil. On the other hand, the monetary approach views money as a principle fundamental to understanding economic relations, themselves considered as the entire set of monetary operations that, to be understood correctly, must be subsumed under goods and services.

With the realistic approach, economic relations function in terms of the rate of exchange in such a way that objects that are deemed genuinely economic are ultimately reduced to physical objects. Consequently, relations between the economic agents and, more fundamentally, the social relations that characterise them, are reduced to simple relations between these physical goods. Hence trade relations are measured through the intermediary of the exchange rate between goods,$^{12}$ regardless of what good serves as a measurement standard; and all prices may be expressed in terms of this good. Meanwhile, from this

\footnotetext{
${ }^{12} \mathrm{X}$ quantity of good $\mathrm{A}$ is exchanged for $\mathrm{y}$ quantity of good $\mathrm{B}$, which in value means that $\mathrm{xA}=\mathrm{yB}$ or that $\mathrm{A}=\mathrm{y} / \mathrm{x} \mathrm{B}$. If we consider a series of partial exchange rates between goods $\mathrm{A}, \mathrm{B}, \mathrm{C}$, and so on, we may make $\mathrm{B}$ the general equivalent constituting a qualitative leap by which C. Benetti (1985), in explaining Marx's analysis of forms of value in the famous section 1 of book 1 of Capital, effectively demonstrates its "metaphysical" character.
} 
"physical" perspective, goods themselves are heterogeneous. Their commensurability is established by means of a theory of value: an "objective" theory of labour-value (which exists in diverse forms in classical political economy) $)^{13}$ or a "subjective" theory of utility-value. In both cases, a theory of real prices then eliminates the monetary dimension of economic relations, the latter having to be derived from real exchanges (Benetti 1981).

The realistic approach basically objects to money being presented immediately as a quantitative reality, its objectivity being social in character and stemming from the prince or the law, that is to say, the political power (Aglietta and Orléan 1999). Now, the fact that money has been thus associated with political relationships-regardless of the socio-institutional forms they may take-has without a doubt disqualified it in the eyes of the founders of the theory of value. Staying with money would have tarnished economic theory from the outset through a false objectivity, one too closely linked to arbitrary policy. Therefore genuine objectivity is to be sought elsewhere than in random social data. Only something like "nature" constitutes an acceptable presupposition. To produce or to find this "nature" once again, one has to build a theory on the basis of a clean social slate, considering goods defined only by their physical-chemical characteristics.

In technical terms, one might track this naturalisation of the economic object to the central postulate that makes the realistic or the value approach operational: the postulate of nomenclature. ${ }^{14}$ This postulate supposes an a priori description of a collection of things, characterised as goods (the theory of utility-value), or as merchandise (the theory of labour-value), prior to and independent of any proposition relative to society. The latter is deemed to be a mere historical variable in which economic acts take place and, as such, is economically nonessential. In other words, specific social forms (exchanges, production, and so on) are built on a neutral substratum: the physical world (Benetti and Cartelier 1981, 94). Thus, this postulate not only signifies that the economic agents know the quality of the goods and the "states of nature" but, more fundamentally, that the particular

\footnotetext{
${ }^{13}$ Here, in a general fashion, we bring together the singular reflections of great thinkers such as Smith and Ricardo who, at a much finer level of analysis, would largely escape the naturalism under which this article's critical perspective claims summarily to categorise them.

${ }^{14}$ We find this again in the formulation of any theory of value, in particular in the dominant neoclassical version.
} 
social-historical forms of production can be neglected. Whether in its dominant neoclassical version or in its Marxist version, ${ }^{15}$ the theory of value is, consequently, based on the postulate of a given list of goods before any other indication relative to individuals or society. From this naturalist perspective, the connection between individuals and society is subsequently constructed as follows:

Individuals define themselves in the collection of goods, the image of nature. They are first natural, before being social, at least according to the naturalist interpretation that has generally been proposed for this postulate of nomenclature. Once this space is admitted, it becomes possible to represent individuals as autonomous entities driven by their own interests, whether expressed on a real scale (real profit) or through a function defined in the space of goods to which selfish interest, supposed to define individual references, may be related [...]. The possible or effective relations between individuals are not only represented in the space of goods. [...] The particular (individual) is linked to the general (society defined in the space of goods), a scientific process giving rise to an explanation of the situation of the former as the effect of a law characterising the latter (Benetti and Cartelier 1995, 221).

Thus, economic theory closely links the quantification of social relations to a particular organisation, the market, the essence of which, once again, should not be confused with its historical form of expression. Individuals present themselves in the market as capable of acting freely according to their own interests and, from this perspective, are not subject to any constraint or dependency external to the market (such as, for example, any form of political, domestic, familial or personal subordination).

The automization of political economy is inseparable from the abstraction of economic relations and their main form of representation by means of the mechanical paradigm of the market. Consequently, this automization diminishes our general knowledge of society: economic subjects are no longer identifiable as political or religious members of society or as part of a family or community. Meanwhile, the construction of an adequate rational representation is further at issue. This is a case of providing a scientific explanation of the nature of economic society (De Vroey 1984a). Since it goes beyond the question of a trade

${ }^{15}$ Here, once more, we employ a shorthand, Marx's theory of value not being at all univocal and also possibly giving rise to an anti-naturalist interpretation, see Cartelier 1991; and Williams 1992. 
agreement and the specific form of socialisation that such an agreement would involve, the issue is then to establish whether it is possible to understand everything that is 'economic' as stemming from this type of socialisation, notably resulting from salary relations.

\section{THE REDEFINITION OF THE WAGE-LABOUR NEXUS}

\section{The wage system and monetary dependence}

In the dominant approach, or the value approach, labour falls into the category of goods. It is identified according to the same principle as any other merchandise, and the labourer is thus raised to the level of a trader who sells a piece of merchandise, labour, the trade of which is not special in any way since it is governed by the rule of voluntary exchange and the principle of equivalence. Since it is limited by the presupposition of the existence of agents providing merchandise, the value approach cannot, therefore, envisage the salary relationship as anything other than a market relationship no different from any other.

Of course, the mode of integration of labour differs depending on whether one adopts the classical viewpoint or the neoclassical viewpoint. From the perspective of the former (excluding Marx), labour is considered as simply physical input and its price, the salary, is predetermined on the basis of a standard of reproduction. The inability to take account of the specificity of wage system relationships may be seen from at least two angles. First, labour, as such, can never be considered as the object of an economic activity to create a good that will be a candidate for exchange. The definition of salary based on a nomenclature of salary-goods does not express a property of the wage system relationship as such, to the extent that, thus defined, the salary refers back to the market relations in which the wage earner is an acquirer of goods.

For Benetti and Cartelier, from the perspective of basic neoclassical models, the special nature of the salary relationship is hardly any better understood. On this model labour is an ordinary good; wage earners are identified as being like any other provider of the factors of production. Now, the least one could say of such a classification is that it is flawed: in his/her status as wage earner, and in his/her necessary lack of access to goods other than labour, the employee cannot participate in any relationship that follows the rules of voluntary exchange. For Benetti and Cartelier, the wage-earning relationship is difficult to "formalize" in neoclassical models. Nevertheless, they put forward a model in which 
salary asymmetry is problematic in terms of budgetary constraints (Cartelier 1995; and 1996a). This does not fully take account of the wage-earning relationship as an institution, but at least it permits the opening up of a discussion in the context of neoclassical theory. For Benetti and Cartelier, it is crucial to underline the fact that, within this context, employees' budgetary constraints are not and cannot in any case be similar to those of the economic agents (the entrepreneurs) for whom they work, that is, under whose orders the work is carried out.

The monetary approach of the wage-labour nexus offers the means of reversing this series of difficulties and rethinking not only the problem of economic socialisation on non-naturalist foundations, but also the specific problem of wage socialisation-which the realistic approaches cannot envisage without theoretical recognition of a true salary difference based on the ambiguity of labour as economic property in capitalistic systems. In Marchands, salariat et capitalistes, the particular nature of capitalism is developed in conceptual terms: monetary dependency describes the inequality likely to exist in an economy where money is the form of social connection that is "separation" (Benetti and Cartelier 1980, 64). A focus on the status of dependency is supposed to be specifically "economic", and therefore, uninhibited by any reference to external considerations related to sociological or political domination.

By economic dependency in a market economy, we mean to designate the status of a certain category of economic agent: those who have nothing to sell, not even their skin to be tanned, ${ }^{16}$ since no merchandise is exchanged in the salary relationship. Labour power is merely the metonymic designation of labourers-without-power, incapable of initiating, by themselves and for their own benefit, a process of labour for the market (De Gaudemar 1981). Of course, this inability does not reflect any natural physical or psychological defect. From a heterodox theoretical viewpoint, it is based on a social cleavage: the possession of capital-money, in Marxist terminology; access to investment credit, in Keynesian terms; and monnayage, (access to money) in the terminology of Benetti and Cartelier. The main idea remains the same throughout: only agents initially able to spend money-and thus finance themselves and initiate a labour process the end product of which can be put on sale in the market-are able to play an active role in market production.

\footnotetext{
${ }^{16}$ One could say in reversing Marx's famous expression about the wage earner.
} 
On the other hand, the social integration of labourers/wage-earners is dependent on the initial activity of economic decision makers who have the power of initiative over social production. In the terminology of Benetti and Cartelier, wage-earners are the "declared elements": in their initial advances, decision makers, the "declaring elements", declare them for a certain amount of money with which the wage earners are economically identified and which will allow them to participate in the monetary operations of market consumption. ${ }^{17}$ Without salary relationships the market economy, described on the basis of compartmentalisation into many decision-making trading units, forms an economically homogeneous society, which we identify as the market society. There, all individuals have the same economic status. For if there are differences between decision makers due to differentiated results from market validation-related, in fact, to the unequal availabilities of monnayage-such differences are, by their nature, purely quantitative and all individuals are subject to the same rules.

Can such a hypothesis of homogeneity be helpful in understanding modern economies? The response to this question is at once complex and multifaceted. Certainly Benetti and Cartelier admit that one must incorporate the realistic question of heterogeneity in any discussion worthy of the name; however the way in which they proceed to theorise this incorporation ends by depleting the salary relationship of any substance. Indeed, within the perspective they offer, while we can effectively distinguish the salary relationship as such, we cannot say much about it. We find ourselves forced to place it in a different theoretical category, if not exclude it altogether. Jean Cartelier seems to adopt precisely such a position in his 1996 text, La monnaie:

Admitting that heterogeneous groups exist amounts to recognition that relations of equivalence cannot exist between individuals belonging to distinct groups and that not all economic relations are market relationships. Those that link individuals of different classes must then be the focus of a specific theory (Cartelier 1996b, 86).

Therefore, we must still examine the consequences of such a compartmentalisation in analysing the wage-labour nexus, although Benetti and Cartelier themselves claim to establish the concept in specific economic terms.

\footnotetext{
${ }^{17}$ Let us remember that this can only be a case of final non-productive consumption.
} 


\section{The limits of such a positioning for the development of heterodox economic analysis}

Remaining strictly in the field of economic relations for which they construct this model of social specificity, Benetti and Cartelier analyse the salary relationship as a social one characterised by a purely economic asymmetry: the belonging of the "declared elements" (the wage-earners-employees) to economic society is determined by their submission to "declaring elements" (the entrepreneurs-employers), the only economic subjects fully integrated into the market-capitalist order. In this way, wage earners only see themselves as they are through their collective dependency on the declaring elements.

As a monetary relationship, the salary relationship is the only means, in a society founded on separation, to socialise those who are excluded by virtue of the rules of access to money [...]. For (collective) wage earners, socialisation takes place on both sides of the fence. In empirical and approximate terms, it is because the goods that they consume must be produced at the initiative of entrepreneurs that the wage earners are what they are, that is, doubly submitted monetarily (Cartelier 1983, 13-14).

However, in our view, one component worth monitoring is the wage-labour nexus as monetary submission. In this, one deals with the salary connection to labour surreptitiously, by indicating that the true nature of salary, within monetary relations between declaring elements, "describes [integrally] labour that one defines as the mode of submission by which dependency experiences the monetary belonging of the declared element to society" (Benetti and Cartelier 1980, 65). Therefore, the consequence is that from a purely economic perspective, "labour is only thus defined by the wage-labour nexus, and not the opposite" (Benetti and Cartelier 1980, 65). The least one can say of this proposition is that it is paradoxical. Since it confuses the social forms that labour may assume, the salaried form and the independent form (or capitalist society and market society). By making labour always property and the employee always a merchant, the monetary approach can finally no longer explain salaried labour as such.

Indeed, saying of the salary-labour link that it is only monetary submission (or dependency) confuses several aspects of the problem. For Benetti and Cartelier, submission appears through monetary membership in society. Yet from there, we cannot directly deduce that this dependency is exclusively a principle of that submission. While the 
declared elements are economically dominated, this is only due to their expenditures. No other dimension of the issue is raised by Benetti and Cartelier either in Marchands, salariat et capitalistes or in subsequent writings (see Cartelier 1995; 1996a; and 2007). Monetary dependency can only signify one thing, however: the obligation of the declared elements, such as workers, to spend their money on goods and services offered by the separate elements, such as capitalists. Such an obligation is not characteristic of labour, but rather of consumption. Yet within the theoretical framework of Benetti and Cartelier, consumption plays no role whatsoever; at best, it can be dimly perceived through necessitythe necessity to exist, to have access to money-in a social-historical context marked by the growing monetisation of social relations. Thus, we are faced with a form of circular reasoning: the result of the salary relationship, the salaried collectivity in monetary dependency, is the precursor to its description (Lautier and Tortajada 1984). It is not and cannot be something like a theory of the wage-labour nexus in Marchands, salariat et capitalistes or in the research that derives from it; there is only, and at best, a refraction of the salary relationship in a particular form of relationship between economic subjects.

\section{LABOUR, THE LABOUR FORCE, AND THE WAGE-LABOUR NEXUS}

For us, one of the basic limitations of this analysis is that the economic identification of the salary solely from the angle of its spending power eliminates any relationship to work, so that the latter fails to be redefined as a form of submission governed by the salary relationship. This point of view may be clarified and developed by referencing the comments on Marx in the second part of Marchands, salariat et capitalistes, especially note 2: on "the notion of labour". ${ }^{18}$ This note advances two hypotheses about Marx's theory of labour value. The first is a critical hypothesis, and the second is an alternative thesis stemming from the former. These theses are: (1) The concept of labour does not belong to the theory of merchandise as an economically significant notion; and (2) Labour is determined within the theory of the salary relationship.

\footnotetext{
${ }^{18}$ Please see Benetti and Cartelier 1980, 164-167. Obviously, it is not surprising that this type of problem would be discussed on the occasion of a confrontation with Marx, since this is the author who first theorised the salary relationship and made it one of the institutions specific to the capitalist mode of production.
} 
These two theses are then developed by Benetti and Cartelier, starting from the Marxist distinction between abstract and concrete labour. The problem that they raise is how one can know what constitutes, for Marx, the specific social form of existence in economic society such as they envision it within their discussion of the process of its constitution. For them, "Marx answers this on the basis of two notions: value and labour (abstract)" (Benetti and Cartelier 1980, 165). Benetti and Cartelier's judgment of Marx is at best hasty and surely reductive. Therefore, it is worth deconstructing this judgment since it shores up their first critical thesis and reinforces the alternative thesis that the concept of labour is completely determined by their theory of the salary relationship.

This process of reasoning is initially made possible by a primary reduction. We must remember that the two concepts that, for Marx, explain the construction of social reality within the economic order are concrete labour and abstract labour. For Benetti and Cartelier, however, these two dimensions are reduced to abstract labour alone. Why is concrete labour abandoned and considered an irrelevant concept from their economic point of view? To answer this question, let us return to their argument in Marchands, salariat et capitalistes: "[concrete labour] is, for Marx, associated with things. Thus, everything that could be said about it has the same status as what could be said about things" (Benetti and Cartelier 1980, 164); that comes from a discourse prior to political economy, and which, as such, has nothing to do with economics. Clearly, Benetti and Cartelier are confusing two distinct conceptual levels: the general notion of labour which belongs to Marx's philosophy and the concept of concrete labour which belongs to Marx's political economy. Since these two terms tend to be conflated, let us pause to explain them.

\section{The critique of the general concept of labour}

For Marx, the general concept of labour stems from philosophical anthropology in as much as it concerns a generic or universal definition of the human condition. Let us recall that for Marx the general notion of labour has two key aspects, the technical and the artistic. Certainly the technical aspect is the best known. We find it discussed in a famous section from Capital, volume 1, chapter 6. "Labour" designates a process or the application of a form of labour to the object of labour through explicit labour activity under the continuous control of the mental representation of the desired product. In this sense, labour is, first and 
foremost, a technical activity by which human beings, from a transhistorical perspective, measure themselves against nature, draw upon their mastery, and rationally govern their organic exchanges with it. It is at this level that some forms of labour exploitation (of one class by another) can develop in history, the capitalist mode of production being seen by Marx as a particular historical form of labour exploitation.

However, this aspect of the problem merely touches one element in Marx's thinking. The economic and philosophical manuscripts of 1844 (Marx 1932 [1844]) indicate what aspect of labour most profoundly affects human beings. There labour is depicted as the act by which human beings relate to themselves as universal beings or, more precisely, as the activity in which they each become aware within themselves of all their own humanity and thus of all humanity. At this level, forms of alienation may develop in certain historical modes of production, the organisation of society leading some of its members to be deprived of this creative and fulfilling dimension of labour activity. While it is not our purpose to develop a detailed explanation of these two aspects of labour here, we would nonetheless stress that it remains a question of two aspects that workers have fully attributed to themselves at the end of history (from a Marxist point of view), in the communist society where they will be liberated from exploitation and alienation. Indeed, it is from this utopian point of view that anthropology may connect with history in the form of a social critique (Sobel 2011).

We fully agree with Benetti and Cartelier that the Marxist notion of labour in general is economically undetermined, in the sense that, for Marx, the determination of an economic category is linked to a particular mode of production. For Marx, this concept represents a fundamental philosophical precondition without which nothing intelligible may be advanced with respect to human societies by any social science. Yet, while it may be necessary, such an anthropological foundation is still insufficient for an understanding of the social form of existence under capitalist modes of production. On this point too we agree with Benetti and Cartelier's contention that philosophicalanthropological considerations are not, as such, directly relevant in the academic discourse of political economy or in its critique. ${ }^{19}$ There is an

19 In this, they are returning to the thesis of Louis Althusser (1965) on the epistemological break between Marx's early writings (where general anthropological categories dominate) and his mature works (where Marx constructs a genuine historical science of modes of production). 
inevitable epistemological gap at the heart of economic discourse: philosophical notions cannot be placed on the same level as scientific concepts.

\section{Concrete labour and abstract labour}

Nonetheless, this is not the same as saying that "concrete labour is therefore economically undetermined" (Benetti and Cartelier 1980, 165). Here we find an unjustified slide between the concepts of "labour in general" and "concrete labour". For our part, we believe that it allows Benetti and Cartelier to ignore all issues of labour (in the sense of production) in their analysis of economic socialisation. Thus, if their argument is convincing for labour in general, it is inapplicable to concrete labour. For Marx, the conceptual opposition of concrete labour and abstract labour is specific and not synonymous with a senseless opposition of heterogeneous terms, the opposition between "labour in general" and "abstract labour".

Such assimilation aims to pass over another opposition as well: that between nature and social reality. With labour in general-a philosophical anthropological concept-human beings are dealing with the things in nature that they transform. Yet "labour in general" cannot exist except in particular historical forms, which Marx calls "concrete labour" - a form of labour where humans are no longer concerned with things in general, but henceforth with social objects defined in and by socially and historically determined practices. Here we leave the level of philosophical anthropological analysis to enter that of Marxist science, the economic analysis of modes of production and different forms of the division of labour. In our view, this change of perspective from labour in general to concrete labour is the effect of an unjustified rejection of the hypothesis of nomenclature characteristic of the monetary approach. Let us remember that, so long as it remains legitimate to consider social factors as the priority,

the presupposition that the point of departure of economic reflection is the existence of a physical world existing independently prior to all social activities emphatically rules out any attempt to describe objects or subjects of economic activity as products of specific social relations (Benetti and Cartelier 1980, 115).

Rejecting the hypothesis of nomenclature as an analytical foundation does not mean abandoning attempts to take it into account 
in social scientific analysis. Otherwise, we would merely be shifting problems. The enigma of this nomenclature, given a priori to use values (nature) would then be replaced by the enigma of the structure and history of its component relations (social factors). May we then avoid the explanation of different forms of divisions of labour, of modalities of concrete work producing multiple use-values? Here we find the habitual false interpretation of Marx that effectively reduces him to an unconscious neo-Ricardian: we attribute to him a point of departure, an a priori social-technical matrix which would, at most, be considered as a natural substratum, to cover social determinations a posteriori, without any true necessary correlation. Now, we must remember that Marx's Capital begins with an account of a mode of social emergence that is historically determined and speaks, not of (natural) things, but of commodities: objects that are already the products of labour. Objects perceived as socially and historically determined, and are the result of commercial exchanges dominated by capitalist logic.

In these conditions, it is simply false to say that in Marx's theory of value the concept of abstract labour has the role of ensuring "the social representation of things" (Benetti and Cartelier 1980, 165). Rather it is through the dual concept of concrete labour and abstract labour, and thus through the very movement away from abstraction, that this representation is considered. To support their thesis, Benetti and Cartelier quote the following passage from Capital:

This is no longer, for example, a table or a house or a wire or some useful article; neither is it the product of the work of a lathe operator, a mason, or of any determined productive labour. Along with the disappearance of the particular useful nature of products of labour, the useful nature of work contained within them disappears at the same time, as do the diverse concrete forms that distinguish one type of labour from another. Therefore, there only remains the common character of this work (Benetti and Cartelier 1980, 165).

Now, in Marxist commodity theory, abstract labour-regardless of its content-does not in itself support all the weight of social factors. Indeed, when Marx studies commodities, he does not naively envisage the use value as the useful aspect in itself but quite the contrary; he sees the use value as the already existing social support (that is, socially determined) of a relation of production. At the risk of regressing to a pre-Marxian theoretical exertion, what we must thoroughly grasp is that the use-value of the commodity is not, for example, the useful 
nature of the object-table, but the useful nature of the commodity-table. The distinction between the use value and utility of the object is a distinction belonging to Marxist economic analysis, although in the current representation, we confuse these two notions: the buyer of the table does not buy the economic concept "use value of the table" but the table itself which will prove useful to him or her later on. ${ }^{20}$

In hypothesising about Marx's depiction of abstract labour, Benetti and Cartelier state that it is not a representation of social factors but rather is purely nominal. In so doing, their argument is reinforced by their critique of real approaches for denying the essentially monetary expression of social substance. Labour is the universal factor arising from pure analytical convention: "given the universality already attributed to labour, there is no more room for the other universal which is money. Therefore, it is only in pushing this away that we may introduce that" (Benetti and Cartelier 1980, 166). ${ }^{21}$

Now, Carlo Benetti and Jean Cartelier claim that if this analytical space is empty. Empty because it was emptied of its legitimate content by Marx. Emptied, that is, of "the monetary (social) expression of value" (Benetti and Cartelier 1980, 166). In a very enlightening critical comment, Bernard Guibert remarks ironically that:

once this illegitimate suppression has taken place, the place may be occupied by anything at the discretion of the theoretician: for Marx, for example, by abstract labour; for Wiksteed by abstract utility; and for our two authors by access to money, each according to their whims! (Guibert 1980, 125).

Nevertheless, without wholly adopting Marx's perspective, we would also argue that it is useful to pursue his line of thinking as far as possible if one wishes to criticise him at the level of his own theoretical ambition, starting with the particular elements of his analysis. Now, we can only disagree with Marx's observation that if a place "seems" empty, it is because it "is" empty (first slip); and that if it is empty, this is because it "has been emptied" (second slip); and that it has been emptied "by someone" (third slip). This tripartite series of slips leads to the theoretician Marx, the author of the gesture that rejects money;

\footnotetext{
${ }^{20}$ Of course these buyers are individuals socialised in a historically determined society, and unless they are themselves (heterodox) economists or, more broadly, social science researchers, they lack a theoretical understanding of the ins and outs of the economic system in which their needs are met.

${ }^{21}$ And more recently, see Benetti and Cartelier 1999.
} 
but it evidently disregards the Marxist theory of fetishism, the blind and social process of displaying the products of labour. Now, Marxist analysis shows us precisely how relationships between things substitute for relationships between human beings, so that the latter become invisible, and the façade of commodities (reification) obscures their social content, which consists precisely of socially determined labour.

Marx also tells us that the laboratories of production are secret because walls prevent us from penetrating the enigmas. There is thus work for the economist and, for Marx, this is clearly work that is appropriate for economists. Benetti and Cartelier think differently: these laboratories are empty for the economist, or-and it amounts to the same thing-if there is something in these laboratories, it does not concern the economist as such. Following Bernard Guibert, however, we may legitimately wonder:

Are they [really] empty? Yes, says the language of commodities, and it fills them in, giving them their monetary names. No, says Marx, the place is already occupied by exploited labour. The chattering of commodities allows for the exploitation of the labour that produces them (Guibert 1980, 125). ${ }^{22}$

From this point, fully reintegrating labour into the economic analysis of capitalism requires giving consistency to a dependence which signals the monetary approach while preventing, as we have demonstrated, a thorough examination of that issue. Marx had indicated that the path to introducing the concept of labour power allowed him to add theoretical depth to the capital-labour relationship, which was for him a relationship of social domination. Is a simple return to Marx on this point sufficient? Nothing is less certain. The concept of labour power is problematic and we can readily understand any hesitation in using it,

${ }^{22}$ For a similar critique, see what Michel De Vroey (1985) writes:

The path of Benetti and Cartelier could be identified as Wittgensteinian minimalism. Not only do they reject the substance and grandeur of value, equilibrium and gravitation with which we would personally agree; they also discard another central tenet of Marx, the connection between the physicaltechnical axis and the social axis. Only the latter is retained, the other being relegated to the impenetrable secret laboratory. Personally, we regret this last break, the impact of which is fundamental. We admit that the proper subject of economic discourse is the social relationship, and not the underlying physicaltechnical dimension. But it is not because the discourse can say nothing in itself on the latter that it is right to abandon it (De Vroey 1985, 406). 
in the same way we can understand its rejection by the field of economic analysis.

\section{The particular nature of the labour force and the issues involved in a shift in theoretical perspective}

The entire problem stems from the fact that labour power is not an object that is easy to grasp within the field of economic analysis. Nevertheless, for it to be relevant at all, an economic theory must recognise the particular or "ontological" nature of labour power within the capitalist mode of production. This is clearly an entirely different task from the essentially critical task of this article. Without claiming to settle the debate, however, we will content ourselves with clarifying a few theoretical issues to support the critical interpretation we are presenting.

Contrary to the classical economists, who are at best ambiguous on this point, Marx argued that labour was not a commodity. Yet the perspective he substituted for theirs (labour power as a commodity) is itself insufficient to explain the specificity of the wage-labour nexus. In the French heterodox domain, some work (Aumeeruddy, et al. 1979; Lautier and Tortajada 1982; M. De Vroey 1985) published around the same time as Marchands, salariat, et capitalistes did, in fact, demonstrate that, contrary to the prevalent interpretation of Marx, ${ }^{23}$ labour power itself cannot strictly be considered as a commodity. ${ }^{24}$ Yet to the extent that labour power is indistinguishable from its holder and, at the same time, does not represent all of a person, one is obliged to ask what theoretical status one should accord the object "labour power" within political-economic discourse. To what degree does this rupture with current economic analytical forms give us positive

\footnotetext{
${ }^{23}$ Marx's thought is not homogeneous and, upon closer examination, itself includes a heterodox perspective that lifts him from a homogeneous and finally ahistorical approach to the economic value approach. On this point, see Maunoury 1984; and De Vroey 1985.

${ }^{24}$ In the strict sense of the term, labour power cannot be a commodity since its production is fundamentally not the result of any professional private labour, as all commodities produced under the conditions of a decentralised market economy must be. In fact, there is no productive consumption integrated in the process of labour whose immediate result would be labour power. Furthermore, a commodity only truly becomes such when it is sold, that is, recognised socially in the market. There again, the sale of labour power does not validate any private professional work. Indeed, the cost of the reproduction of the worker is comprised of domestic work, that is, of private professional labour incorporated in the salary commodities consumed that were already validated as such since they were purchased by the worker in the market of goods.
} 
theoretical content to the labour force, that is, to give content to the very economic dependence which characterises the wage-labour nexus?

We can perhaps appreciate the degree of rupture by briefly referencing two attempts in this regard, those of Michel De Vroey and of Bruno Théret. De Vroey suggests considering labour power as a natural resource, that is, "a use-value at the disposition of men by nature and whose available quantity is not the effect of work" (De Vroey 1985, 460). The salary transaction could then be interpreted as "a transfer of rights of usage of a natural resource of an owner who lacks the means to put it to work to a purchaser who has the means" (De Vroey 1985, 461). However, De Vroey's solution remains partial. What is at stake here is, at the very least, a special type of natural resource since it is not, like other natural resources, a pure external and appropriable object but one which simultaneously refers to the legal subject who is its owner.

A definitive solution might consist of making a radical break with any "naturalist" conception of labour power. The latter can only be reduced to a pure expenditure of energy when one accords its holder the status of a legal-political subject..$^{25}$ Certainly, with the theory of regulation, Bruno Théret (1994) was able to proceed furthest with the implications stemming from the specific status that one must accord labour power in a society whose economic order is dominated by market capitalism and whose political order is structured by a state of law, and, in formal terms, by a democratic state. From the perspective of salaried workers, meanwhile, representing nothing more than merely a labour force in the economic order causes identity problems. Such selfdistancing, in principle prior to the salary transaction, is never a given. This distancing is always a symbolic construction orchestrated by an entire network of rules, ${ }^{26}$ essentially destined to focus on wage labourers/salaried workers over the course of the labour contract by giving them a role as holders of a "fictional commodity" ${ }^{27}$ that is their own labour power (Castel 2002). Now, this symbolic construction is nothing more than the product of history. Without further developing Bruno Théret's perspective, let us insist on the intrinsically historical

\footnotetext{
${ }^{25}$ That is to say, as soon as we distinguish the wage system from the different historical forms of forced labour (serfdom, slavery, and so on) and we place ourselves in the context of a rule of law where salaried workers are also subjects. This is historically the case for those nations in which capitalism developed (notably the states of Western Europe and the United States).

${ }^{26}$ This aspect is especially clarified by the economic analysis of conventions. See Eymard-Duvernay 2007.

${ }^{27}$ Bruno Théret uses the apt expression of Karl Polanyi (1983).
} 
character of the change in theoretical perspective to which we are led. From pure theory, claiming to be heterodox-like the capitalistmonetary approach where salary dependence and socialisation are underdetermined-we must move on to an institutionalist approach, a mode of theorization adapted to objects which are by nature floating outside of history but are in large part "social-historical" ${ }^{28}$ constructions, irreducible to earlier forms.

It is, thus, a matter of studying different histories of the socialpolitical integration of economic non-owners, the salaried workers. To examine how they are constructed, how they function, and how they transform themselves into different collective institutions (via labour law, collective conventions, and social protection) that, without radically changing the nature of the relations of production, give effective content to salary socialisation at each stage of capitalism and other socio-cultural contexts. This is the path, for example, still followed by the theory of regulation (Boyer 1993; and 1995), of which Bruno Théret's research on the salary relationship is still the most theoretically advanced work.

\section{CONCLUSIONS}

The main contribution of the heterodox approach of Benetti and Cartelier is that it questions the relevance of a view of the economy exclusively based on a market perspective. Can the universalist perspective according to which there is no need to raise the fundamental differences between the markets and the agents who participate in them be described as tenable? For Benetti and Cartelier, the answer is clearly no; and the analytical insights of their monetary approach are worth retaining. This conclusion is central to economic research. ${ }^{29}$ To examine the problem of the social connection in capitalistmonetary economies, we have to bear in mind the ambiguous status of workers and of the "labour power" of which they are the enigmatic holders, as we have seen with De Vroey and Théret. Although the monetary perspective leads to a very strict formulation of this problem, this approach has definite limitations. This can be seen especially clearly when one analyses Benetti and Cartelier's interpretation of Marx's concept of labour. In radicalising economic dependence, they deprived

\footnotetext{
${ }^{28}$ We borrow this term from Cornelius Castoriadis.

${ }^{29}$ Obviously, we are aware of the daunting scale of this task.
} 
it of all substance. In so doing, they place economic science before a problematic alternative which is far from being resolved.

Either we think "purely" of capitalism, theorising that economic agents are the only subjects ("the declarative elements"), but at the cost of neglecting an analysis of wage labour; or we integrate salaried work into our theoretical model. The former, as we have seen, leads to the perspective suggested by Benetti and Cartelier, who are at least consistent in saying that political economy, as such, ultimately has nothing specific to say about salary socialisation and that we must leave this task to other fields of academic discourse (the socio-economy of labour and employment, for example). Insofar as the dominant option today with respect to the theorization of capitalism is the integration of wage labourers as merchants, we have, with this model, considerably regressed with respect to the theoretical position of the heterogeneity of statuses.

To integrate salaried work, meanwhile, one has to accept the difficult task of describing, once it is correctly understood, the precise nature of labour power. This is a task which involves the socialhistorical theorization of modes of integration of salaried workers, for example in the Marxist wake of the most applied research of the 'school of regulation'. Despite being challenging, this clearly marks the opening of a genuine economic heterodoxy to other social sciences. Thus, the question is the following: are the adherents of the alternative paradigm ready to accept the consequences of the theoretical recognition of heterogeneity? To this point, the academic field of economics has been structured around the need for an economic theory that would remain both homogeneous and extremely abstract. Any actors or institutions that might seek to adopt an alternative, heterodox, social-historical position would inevitably be breaking away from the dominant academic. At best, such a break would lead to the creation of institutionalism; at worst, to socio-economy. Either way, such is the foothold of "abstraction" in orthodox economics that neither outcome would result in what academia comprehends as economic theory.

This is the entire issue of the initiative launched by Alain Caillé, Robert Boyer and Olivier Favereau starting with the Manifeste pour une économie politique institutionnaliste (2007). This initiative attempts to start again with the business of constructing an alternative paradigm. It seeks to do so, not by refocusing on a rigid theoretical foundation at the risk of falling into purism (one of the imitations of the Benetti- 
Cartelier approach), but in drawing from a collection of heterodox approaches. One of the possible criticisms that could be raised is that this eclecticism risks resulting in a certain heterogeneity, at least in terms of its general theoretical nature. A lesson that could emerge from our critical perspective on the approach of Benetti and Cartelier is that a heterodox theoretical process must ensure a balance between historical relevance (going beyond simple description) and conceptual precision (moving beyond abstraction for its own sake, or esotericism).

Consequently, thirty years after the publication of Marchands, salariat et capitalistes, we are presented with this alternative in principle, even if the question has in fact already been resolved, the former term having carried the day in the academic domain in France, as in other countries. Yet one point remains incontrovertible: the theoretical recognition of the heterogeneity of capitalism, however necessary, cannot be accomplished in a homogenous paradigm and most certainly not from within neoclassical theory. This only leaves the question: what is an economic theory that has nothing pertinent to say about capitalism and its forms of social integration?

\section{REFERENCES}

Aglietta, Michel, and Anton Brender. 1984. Les métamorphoses de la société salariale. Paris: Calmann-Lévy.

Aglietta, Michel, and André Orléan (eds.). 1999. La monnaie souveraine. Paris: Odile Jacob.

Althusser, Louis. 1965. Lire le Capital. Paris: François Maspero.

Aumeeruddy, Aboo T., Bruno Lautier, and Ramon G. Tortajada. 1978. Labour power and the state. Capital \& Class, 2 (3): 42-66.

Benetti, Carlo (ed.). 1981. La formation des prix: A. Smith, D. Ricardo, and K. Marx. Cahiers d'Économie Politique, n. 6.

Benetti, Carlo. 1985. Economie monétaire et économie de troc: la question de l'unité de compte commune. Economie Appliquée, 1985 (1): 85-109.

Benetti, Carlo, and Jean Cartelier. 1980. Marchands, salariat et capitalistes. Paris: François Maspero.

Benetti, Carlo, and Jean Cartelier. 1987. Monnaie, valeur et propriété privée. Revue économique, 38 (6): 1157-1170.

Benetti, Carlo, and Jean Cartelier. 1995. L'économie comme science: la permanence d'une conviction mal partagée. In L'économie devient-elle une science dure?, eds. A. d'Autume, and J. Cartelier. Paris: Economica, 216-232.

Benetti, Carlo, and Jean Cartelier. 1998. Money form and determination of value. In Marxian economics: a reappraisal (Essays on volume III of Capital: method, value and money), ed. Riccardo Bellofiore. London: MacMillan, 157-171.

Benetti, Carlo, and Jean Cartelier. 1999. Market and division of labour: a critical reformulation of Marx's view. Rivista di Politica Economica, 89 (4-5): 117-140. 
Boyer, Robert. 1993. Labour institutions and economic growth: a survey and a "regulationist" approach. Labour. 7 (1): 25-72.

Boyer, Robert, and Yves Saillard (eds.). 2002. Regulation theory: the state of the art. London: Routledge.

Caillé, Alain (with Olivier Favereau, Robert Boyer, José Luis Corragio, Peter Hall, Geoffrey Hodgson, Marx Humbert, Ahmet Insel, Michael Piore, Ronen Palan, Paul Singer, Bob Jessop, Jean-Louis Laville, Michel Lallement, Philippe Steiner, and François Vatin). 2007. Toward an institutionalist political economy. Revue $d u$ MAUSS, 9 September 2008. www.journaldumauss.net/spip.php?article232 (accesed February 2014).

Cartelier, Jean. 1983. Une introduction à l'économie hétérodoxe. Working Paper $n$. 8302, Université Catholique de Louvain, Louvain, BE.

Cartelier, Jean. 1985. Théorie de la valeur ou hétérodoxie monétaire: les termes d'un choix. Economie Appliquée, 1985 (1): 63-82.

Cartelier, Jean. 1991. Marx's value, exchange and surplus value theory: a suggested reformulation. Cambridge Journal of Economics, 15 (3): 257-269.

Cartelier, Jean. 1995. L'économie de Keynes. Bruxelles: De Boeck.

Cartelier, Jean. 1996a. Chômage involontaire d'équilibre et asymétrie entre salariés et non-salariés. Revue économique, 47 (3): 655-666.

Cartelier, Jean. 1996b. La monnaie. Paris: Flammarion.

Cartelier, Jean. 2007. The hypostasis of money: an economic point of view. Cambridge Journal of Economics, 31 (2): 217-233.

Castel, Robert. 2002. From manual workers to wage laborers: transformation of the social question. New Brunswick (NJ): Transactions Publishers.

Castoriadis, Cornelius. 1998 [1975]. The imaginary institution of society. Cambridge (MA): MIT Press.

De Gaudemar, Jean-Paul. 1981. Des mystères du logarithme jaune. In Réexamen de la théorie du salariat, de la force de travail individuelle à la reproduction sociale (collective). Lyon: PUL, 7-17.

De Vroey, Michel. 1984a. La procédure de socialisation et le statut des échangistes dans trois représentations théoriques du marché. Economies et sociétés, PE series (Oeconomia), 10: 129-150.

De Vroey, Michel. 1984b. Marchandise, société marchande, société capitaliste: un réexamen de quelques définitions fondamentales. Cahiers d'Économie Politique, n. 9: 109-135.

De Vroey, Michel. 1985. La théorie du salaire chez Marx: une critique hétérodoxe. Revue économique, 36 (3): 451-480.

De Vroey, Michel. 1987. La possibilité d'une économie décentralisée. Esquisse d'une alternative à la théorie de l'équilibre général. Revue économique, 38 (4): 773-806.

Eymard-Duvernay, François. 2007. De la valeur-travail aux institutions de valorisation par le travail. In Le salariat: théorie, histoire et formes, ed. F. Vatin. Paris: La Dispute, 107-123.

Faccarello, Gilbert. 1981. Karl Marx et la problématique des prix naturels. Revue d'Économie Politique, n. 4: 373-397.

Faccarello, Gilbert. 1982. L'échec de Marx: pour rouvrir un débat. Cahiers d'Économie Politique, n. 8: 65-85. 
Gouverneur, Jacques. 1987. Manuel de théorie économique marxiste. Bruxelles: De Böeck.

Guibert, Bernard. 1980. Les ravages de la logique. Critique de l'Economie Politique, nouvelle série, $\mathrm{n}$. 13: 107-129.

Lautier, Bruno, and Ramon Tortajada. 1982. Ecole, force de travail et salariat. Paris: François Maspero.

Lautier, Bruno, and Ramon Tortajada. 1984. A propos de 'Marchands, salariat et capitalistes'. Monnaie, financement et rapport salarial. Cahiers d'Economie Politique, n. 9: 159-194.

Lawson, Tony. 2006. The nature of heterodox economics. Cambridge Journal of Economics, 30 (4): 483-505.

Lazear, Edward P. 2000. Economic imperialism. Quarterly Journal of Economics, 115 (1): 99-146.

Maunoury, Jean-Louis. 1984. Théorie marxiste de la valeur et normes sociales de valorisation. Cahiers d'Économie Politique, n. 9: 85-107.

Marx, Karl. 1932 [1844]. The economic and philosophical manuscripts of 1844. Marx/Engels Internet Archive:

http://www.marxists.org/archive/marx/works/1844/manuscripts/preface.htm (accessed February 2014).

Marx, Karl. 1995 [1867]. Capital: a critique of political economy, Volume 1, Book 1: The process of production of capital. Marx/Engels Internet Archive: http://www.marxists.org/archive/marx/works/1867-cl/ (accessed February 2014).

Polanyi, Karl. 1944. The great transformation. Boston: Beacon Hill.

Polanyi, Karl. 1977. The livelihood of man, ed. H. W. Pearson. New York: Academic Press.

Postel, Nicolas, and Richard Sobel. 2009. Institutionalism as the way of unification of the heterodox theories. The Journal of Philosophical Economics, 3 (1): 47-77.

Postel, Nicolas, and Richard Sobel. 2011. Toward a heterodox theory of the economic actor: the contribution of two French institutionalist schools. History of Economic Ideas, 19 (2): 43-68.

Pouch, Thierry. 2001. Les économistes français et le Marxisme apogée et déclin d'un discours critique (1950-2000). Rennes: Presses Universitaires de Rennes.

Schumpeter, Joseph. 2000 [1954]. History of economic analysis. London: Taylor and Francis.

Schwab, Laurent, Alain Le Diberder, and Philippe Steiner. 1985. Une introduction à l'économie politique hétérodoxe: Marchands, salariat et capitalistes. Revue économique, 36 (2): 411-424.

Sobel, Richard. 2011. Necessity and liberty in the communist utopia: André Gorz's rereading of Marx. Rethinking Marxism, 23 (2): 265-281.

Théret, B. 1994. Le salariat comme forme de l'interdépendance entre l'Etat et le marché. In L'Etat et le marché, eds. B. Bellon, et al. Paris: Economica, 68-79.

Ulgen, Farük, Ramon Tortajada, Mathieu Méaulle, and Rémi Stellian (eds.). 2013. New contributions to monetary analysis: the foundations of an alternative economic paradigm. London: Routledge.

Williams, Michaël. 1992. Marxists on money, value and labour-power: a response to Cartelier. Cambridge Journal of Economics, 16 (4): 439-445. 
Richard Sobel and Nicolas Postel are assistant professors of economics at the University of Lille 1 (France), and researchers at the laboratory CLERSE-CNRS (http://clerse.univ-lille1.fr/). They have founded and are members of the editorial council of the Revue Française de SocioEconomie (La Découverte/ CAIRN). They are specialists in institutional economics and have co-published the Dictionnaire critique de la RSE (Presse Universitaires du Septentrion, 2013).

Contact e-mail: <richard.sobel@univ-lille1.fr>

Contact e-mail: <nicolas.postel@univ-lille1.fr> 